\title{
The Industrial Transition in Great Britain
}

\author{
By Dr. K. G. Fenelon
}

D URING the post-War years, important changes have been taking place in the distribution of industries and employment in Great Britain. Some of these are well known and the effects are fully appreciated, but concerning others, facile generalisations are frequently made, and this despite the fact that there are few economic problems in which the statistical information available is so abundant.

During the eleven years 1923-34, unemployment has fluctuated from somewhat less than 9 per cent to about 23 per cent, whereas in pre-War days unemployment varied between $2 \frac{1}{2}$ per cent in the best of times to a little more than 10 per cent in the worst. Pre-War unemployment statistics, it is true, are much less adequate than those available to-day, and also certain persons now regarded as unemployed might not have been so regarded before the War, but at any rate it is clear that unemployment is nearly double that of pre-War days. It would be a mistake to imagine that the figures of recent years represent a permanent state of unemployment of something like two million workers, because in actual fact unemployment has been spread in each of these years among five or six million workers - that is, about half of the insured population-some suffering little from unemployment and others severely. There are two kinds of unemployment, one intermittent, the other prolonged, and it is on those in the latter category that the most tragic consequences of the industrial transition have fallen.

How are we to account for the change in the proportion of unemployment since the War? Is it due to the introduction of machinery, and must the inevitable result of scientific progress be that more and more persons will be thrown out of employment? Past experience does not bear this out as inevitable. During the nineteenth century - despite enormous technical progress and a great increase in population-unemployment did not steadily become greater. The popular view that machines are steadily increasing production and at the same time steadily throwing men out of employment cannot be sustained by reference to statistics of production and employment. For example, between 1924 and 1929 the index of production rose from 100 to 111.8 and the employment index increased from 103.8 to 110.5 . Nor would it seem, taking industry as a whole, that men are being displaced by women, whatever may be the case in particular industries or occupations. Census returns show that the occupied female population in England and Wales accounted for 30.4 per cent of the total occupied population in 1881 , for 29.7 per cent in 1911 , for 29.5 per cent in 1921 and for $29 \cdot 8$ per cent in 1931.

After the War, a readjustment from war- to peace-time demands had to be effected, and even more difficult has been the problem of reshaping the structure of British industry to meet the decline in exports which has resulted from industrial development in foreign countries, the imposition of all kinds of restrictions on foreign trade, and technological changes such as the displacement of coal by oil fuel especially in shipping.

Furthermore, the slowing down of the rate of increase of population in so many countries has tended to shift demand from primary to secondary industries, and it is no longer possible for the basic industries providing ordinary necessaries of life to expand at the same rate as was formerly required by ever-increasing populations. These various changes have had severe reactions on British foreign trade, since a disproportionate amount of our industrial resources were engaged in the pro. duction of primary commodities.

The changed fortunes of the various industries are strikingly brought out by figures for the years 1923-34 relating to the number of insured persons in employment issued by the Ministry of Labour and published in the Ministry of Labour Gazette for December last (London: H.M. Stationery Office), from which the following figures have been extracted. Since both 1923 and 1934 were years of incipient recovery after a period of depression, a comparison between them would seem to be permissible, provided it is borne in mind that the insured population increased in this period by a little more than 16 per cent.

Taking first the depressed industries, those which have suffered a loss in employment of upwards of 10,000 persons each since 1923 are listed in Table 1 , fluctuations in employment being shown by means of index numbers for the different years.

Coal mining has shown the greatest contraction owing to loss of export markets, economies in the use of fuel and other causes. The iron and steel trades, on the other hand, have made a marked recovery in recent years owing largely to the tariff. Practically all industries show some improvement in 1934, with the exception of cart and carriage building, which has suffered from the continued development of motor transport.

In marked contrast are the expanding industries, the more important of which, from the point of 
view of additional employment afforded, are set out in Table 2.

Altogether, the expanding industries have given employment to the equivalent of all those displaced since 1923 from the declining industries and have provided employment for nearly a million persons in addition. In these industries, many of rather to its success in attracting new industries. Moreover, its typical industries are luxury trades or light industries which have been less hard hit than the old-established industries of the north.

The economic transition which is slowly working itself out becomes more apparent if the expanding industries are classified in groups as follows:

Table 1.

Contracting Industries. Great Britain and Northern Ireland.

\begin{tabular}{|c|c|c|c|c|c|c|c|c|c|c|}
\hline \multirow{2}{*}{\multicolumn{2}{|c|}{ Industry }} & & & & \multicolumn{2}{|c|}{ Number Employed } & \multicolumn{4}{|c|}{ Index Number of Employment $(1923=100)^{*}$} \\
\hline & & & & & $\begin{array}{c}\text { June } 1923 \\
\text { Aged } 16 \text { and } \\
\text { over } \\
\text { (Thousands) }\end{array}$ & $\begin{array}{c}\text { June 1934 } \\
\text { Aged 16-64 } \\
\text { (Thousands) }\end{array}$ & 1925 & 1929 & 1932 & 1934 \\
\hline $\begin{array}{l}\text { Coal Mining } \\
\text { Cotton } \ldots . . . \\
\text { General Engineering } \\
\text { Woollen and Worsted } \\
\text { Shipbuilding and Ship Repai } \\
\text { Railway ( Non-Permanent Ser } \\
\text { Iron and Steel } \\
\text { Marine Engineering } \\
\text { Boots, Shoes, etc. } \\
\text { Textile Finishing } \\
\text { Jute } \\
\text { Pig Iron (B.... } \\
\text { Carriages, Carts, Furnaces) } \\
\text { Dress-Making and Millinery }\end{array}$ & $\begin{array}{c}\ldots \\
\ldots \\
\cdots \\
\cdots \\
\text { iring } \\
\text { rvice) } \\
\cdots \\
\cdots \\
\cdots \\
\cdots \\
\cdots \\
\cdots \\
\cdots \\
\cdots\end{array}$ & $\begin{array}{l}\cdots \\
\cdots \\
\cdots \\
\cdots \\
\cdots \\
\cdots \\
\cdots \\
\cdots \\
\cdots \\
\cdots \\
\cdots \\
\cdots \\
\cdots \\
\cdots \\
\cdots \\
\cdots \\
\cdots\end{array}$ & $\begin{array}{l}\cdots \\
\cdots \\
\cdots \\
\cdots \\
\cdots . \\
\cdots . \\
\cdots \\
\cdots \\
\cdots \\
\cdots \\
\cdots \\
\cdots \\
\cdots \\
\cdots \\
\cdots \\
\cdots \\
\cdots\end{array}$ & $\begin{array}{c}\cdots . . \\
\cdots . \\
\cdots . \\
\cdots . \\
\cdots . \\
\cdots . \\
\cdots . \\
\cdots . \\
\cdots . \\
\cdots . \\
\cdots . \\
\cdots . \\
\cdots . \\
\cdots .\end{array}$ & $\begin{array}{r}1,212 \\
445 \\
526 \\
251 \\
151 \\
179 \\
167 \\
51 \\
129 \\
102 \\
36 \\
26 \\
24 \\
110\end{array}$ & $\begin{array}{r}623 \\
360 \\
444 \\
181 \\
81 \\
121 \\
127 \\
33 \\
112 \\
86 \\
20 \\
12 \\
12 \\
98\end{array}$ & $\begin{array}{r}75 \cdot 8 \\
117 \cdot 7 \\
103 \cdot 9 \\
81 \cdot 7 \\
103 \cdot 6 \\
88 \cdot 3 \\
88 \cdot 1 \\
94 \cdot 0 \\
100 \cdot 6 \\
111 \cdot 2 \\
98 \cdot 4 \\
75 \cdot 2 \\
92 \cdot 3 \\
92 \cdot 0\end{array}$ & $\begin{array}{r}74 \cdot 0 \\
109 \cdot 0 \\
105 \cdot 8 \\
85 \cdot 2 \\
108 \cdot 9 \\
76 \cdot 1 \\
89 \cdot 6 \\
105 \cdot 9 \\
93 \cdot 1 \\
102 \cdot 8 \\
98 \cdot 2 \\
80 \cdot 7 \\
74 \cdot 0 \\
91 \cdot 7\end{array}$ & $\begin{array}{l}52 \cdot 7 \\
79 \cdot 8 \\
77 \cdot 3 \\
70 \cdot 7 \\
46 \cdot 4 \\
65 \cdot 6 \\
54 \cdot 0 \\
42 \cdot 2 \\
85 \cdot 6 \\
84 \cdot 5 \\
56 \cdot 3 \\
42 \cdot 6 \\
61 \cdot 9 \\
87 \cdot 7\end{array}$ & $\begin{array}{l}53 \cdot 0 \\
81 \cdot 9 \\
87 \cdot 7 \\
74 \cdot 9 \\
55 \cdot 5 \\
69 \cdot 9 \\
79 \cdot 2 \\
65 \cdot 2 \\
89 \cdot 4 \\
87 \cdot 7 \\
58 \cdot 6 \\
51 \cdot 0 \\
52 \cdot 2 \\
89 \cdot 2\end{array}$ \\
\hline
\end{tabular}

* A direct comparison between 1923 and 1934 is not possible owing to administrative changes in the insurance scheme

in 1927 , but the index numbers are based on estimates which serve to link up the figures before and after 1927 .

the factories recently built are not inferior to any in the world in respect of equipment, layout or technique.

Further information regarding industrial development has recently been published in a Survey issued by the Board of Trade, which shows that 463 new factories employing 29,500 persons were established in 1933, of which 220 were located in Greater
(1) distributive trades and road transport; (2) building and public works contracting, including the construction and provision of materials for houses, shops, public buildings, roads, drainage and other communal services; (3) administrative and organising services, including those of local government, insurance, banking, education, health, office employment and scientific research ; (4) new

Table 2.

Expanding Industries. Great Britain and Northern Ireland.

\begin{tabular}{|c|c|c|c|c|c|c|c|c|c|}
\hline \multirow{2}{*}{ Industry } & & & & \multicolumn{2}{|c|}{ Number Employed } & \multicolumn{4}{|c|}{ Index Number of Employment $(1923=100)$} \\
\hline & & & & $\begin{array}{c}\text { June } 1923 \\
\text { Aged } 16 \text { and } \\
\text { over } \\
\text { ('Thousands) }\end{array}$ & $\begin{array}{c}\text { June } 1934 \\
\text { Aged } 16-64 \\
\text { (Thousands) }\end{array}$ & 1925 & 1929 & 1932 & 1934 \\
\hline $\begin{array}{l}\text { Distributive Trades } \\
\text { Building .... } \\
\text { Hotels, Restaurants, etc. } \\
\text { Tram and Bus Services } \\
\text { Motor-Vehicles, Cycles and Aircraft } \\
\text { Local Government } \\
\text { Electric Cables, Lamps, Apparatus, } \\
\text { Other Road Transport.... } \\
\text { Public Works Contracting } \\
\text { Printing, Publishing, etc. } \\
\text { Laundries, Dyeing and Dry cleaning } \\
\text { Entertainments and Sports } \\
\text { Professional Services .... } \\
\text { Furniture .... } \\
\text { Commerce, Banking, Insurance, etc. } \\
\end{array}$ & $\begin{array}{l}\ldots . \\
\ldots \\
\ldots \\
\ldots \\
\ldots \\
\ldots . \\
\text { etc. } \\
\ldots \\
\ldots \\
\ldots \\
\ldots \\
\ldots \\
\ldots \\
\ldots \\
\cdots\end{array}$ & $\begin{array}{l}\ldots . . \\
\ldots . \\
\ldots . \\
\ldots . \\
\ldots . \\
\ldots . \\
\ldots . \\
\ldots . \\
\ldots . \\
\ldots . \\
\ldots . \\
\ldots . \\
\ldots . \\
\ldots . \\
\ldots . \\
\ldots .\end{array}$ & 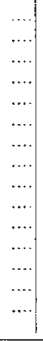 & $\begin{array}{r}1,181 \\
626 \\
233 \\
105 \\
174 \\
228 \\
65 \\
123 \\
103 \\
215 \\
101 \\
52 \\
104 \\
87 \\
217\end{array}$ & $\begin{array}{r}\mathbf{1}, 801 \\
790 \\
359 \\
174 \\
246 \\
295 \\
122 \\
176 \\
153 \\
257 \\
143 \\
92 \\
141 \\
118 \\
246\end{array}$ & $\begin{array}{r}116 \cdot 9 \\
112 \cdot 6 \\
117 \cdot 6 \\
110 \cdot 6 \\
116 \cdot 4 \\
104 \cdot 7 \\
116 \cdot 4 \\
113 \cdot 2 \\
125 \cdot 1 \\
107 \cdot 9 \\
110 \cdot 3 \\
113 \cdot 7 \\
105 \cdot 9 \\
110.5 \\
98 \cdot 6\end{array}$ & $\begin{array}{l}136 \cdot 9 \\
126 \cdot 8 \\
136 \cdot 3 \\
147 \cdot 5 \\
134 \cdot 4 \\
120 \cdot 1 \\
139 \cdot 3 \\
136 \cdot 0 \\
136 \cdot 0 \\
119 \cdot 7 \\
131 \cdot 1 \\
130 \cdot 7 \\
115 \cdot 6 \\
135 \cdot 2 \\
103 \cdot 4\end{array}$ & $\begin{array}{l}149 \cdot 0 \\
106 \cdot 2 \\
141 \cdot 8 \\
167 \cdot 0 \\
114 \cdot 4 \\
133 \cdot 9 \\
158 \cdot 5 \\
138 \cdot 5 \\
188 \cdot 0 \\
122 \cdot 1 \\
136 \cdot 5 \\
155 \cdot 5 \\
126 \cdot 2 \\
126 \cdot 9 \\
107 \cdot 4\end{array}$ & $\begin{array}{l}155 \cdot 4 \\
132 \cdot 5 \\
156 \cdot 7 \\
170 \cdot 2 \\
143 \cdot 2 \\
139 \cdot 6 \\
189 \cdot 3 \\
147 \cdot 0 \\
154 \cdot 7 \\
122 \cdot 5 \\
143 \cdot 6 \\
180 \cdot 9 \\
138 \cdot 0 \\
140 \cdot 9 \\
114 \cdot 2\end{array}$ \\
\hline
\end{tabular}

London, 94 in the north-west of England and 63 in the Midlands. In the same year, there were 95 factory extensions, while $\mathbf{4 0 9}$ factories were closed down. Only three of the new factories represented transfers from the north to the south, and of these, two were aircraft factories. The growing industrialisation of the south of England has been due not to the transfer of factories from the north, but industries and the manufacture of specialised products.

The changes in industrial structure revealed by the statistics reflect deep-seated economic and social changes in the life of the community. As examples we may refer to housing, the great development of which is revealed by the fact that between 1923 and 1933 inclusive, some $1,800,000$ 
houses have been built in England and Wales. The spread of leisure has led to a marked expansion in entertainment and sport, while changes in social and domestic habits account for the development of bus travel, the growth of restaurant and hotel businesses and the expansion of laundry and similar trades which provide services formerly carried on in the home.

The new manufacturing industries are much more numerous than is commonly supposed, though the development of many of them is hidden under the generic names in the Ministry of Labour's list. In the development of new industries, or the recent expansion of the old-established trades, scientific discovery or the application of science has played an important part. A long list of such products could be given, but it must suffice to mention rayon; aircraft; motor-cars; electric cables, lamps, motors and apparatus; radio; neon signs; photo-electric apparatus; pharmaceutical chemicals; detergents; synthetic resins and other plastic materials ; cinematograph films ; refrigerators; solid carbon dioxide; chromium plating; cellulose products; and canned foods. Indeed, the extent to which scientific research is transforming methods of production is seldom fully realised, and, as was stated in a report of the Department of Scientific and Industrial Research, "in nearly every industry to-day, movements are on foot to apply old materials to new uses or to discover uses for new products".
In rayon, the relation of science to industry is conspicuously close, and this industry has made rapid progress in those countries which possessed a well-developed chemical industry. Other thriving new-comers are the plastic industries; the products of which are now extensively utilised not only for accessories of all kinds, but also in the manufacture of silent gear wheels and in chemical engineering, where their resistance to boiling acids and corrosive fumes are of value. Canning is another industry which has recently made rapid progress in Great Britain ; expanding its production from about 2-3 million cans in 1925 to more than 100 million cans in 1931. Special problems had to be overcome on account of the high acid content of British fruit, and the difficulties in preserving the colour and flavour. Many ingenious machines have been constructed by British manufacturers for this industry.

In connexion with the building-up of new export trades, scientific applications are an essential asset. Specialised products, combining high quality with skilled workmanship, are frequently assured of a ready sale overseas, such as has been achieved by British manufacturers of light aeroplanes, motor-cars and electrical apparatus. An interesting illustration of the advantages of scientific specialisation in export industries is the almost exclusive utilisation of British photographic and projection lenses in the film studios of Hollywood.

\section{The Professors of the Royal Institution}

\section{By Thomas Martin}

$\mathrm{B}^{\mathrm{Y}}$ the election on May 7 of Sir James Jeans as professor of astronomy in the Royal Institution, its members have exercised a privilege which has not been used since 1863. Faraday was then the Fullerian professor of chemistry, but he was in his declining years, and Dr. (afterwards Sir Edward) Frankland was elected to a separate professorship of chemistry. Frankland discharged the duties until shortly after Faraday's death in 1867, when Odling became the Fullerian professor and Frankland's professorship was allowed to lapse. The other 'elected' professorship in the Institution at the time, that of natural philosophy, had been established ten years earlier; and was not so short-lived. It was created for John Tyndall when he went to the Institution in 1853 , to become the friend and colleague of Faraday in the last fourteen years of his life ; and it has continued by election and re-election to the present day.

Lectures on scientific subjects, to be given in a lecture room with the most up-to-date facilities for experiment and demonstration, were a part of the original scheme drawn up in 1799 by the founder, Benjamin Thompson, Count Rumford; and when Rumford's proposals were adopted and the Royal Institution of Great Britain came into existence, the "teaching by courses of philosophical lectures and experiments the application of science to the common purposes of life" was recited as one of its objects in the Royal Charter granted by King George III. The lecture room was constructed, under Rumford's personal supervision, at the house which had been purchased in Albemarle Street; and the procedure to be followed in appointing professors and lecturers was laid down in the by-laws given to the new Institution. The professors were to be elected annually by ballot, and a new professorship could be established at any time, by resolution proposed by fifteen members, which must be carried at one general monthly meeting and confirmed at the next. 